\title{
A prospective randomized study of the natural history of idiopathic scoliosis versus treatment with the SpineCor brace
}

\author{
C Coillard*, A Circo, C Rivard
}

From 8th International Conference on Conservative Management of Spinal Deformities and SOSORT 2011

Annual Meeting

Barcelona, Spain. 19-21 May 2011

\section{Background}

The purpose of this randomized study was to evaluate the effectiveness of the Dynamic SpineCor brace [1,2] for early adolescent idiopathic scoliosis $\left(15^{\circ}-30^{\circ}\right)$ compared to the natural evolution of the disease. 47 patients participated in this study (26 treated and 21 controls).

\section{Material and methods}

The inclusion criteria where: 1) High risk of evolution: family history and/or proven progressive 2) No significant pathological malformation of the spine; 3) Girl or boy; 4) Initial Cobb angle between $15^{\circ}$ and $30^{\circ}$; 5) Risser 0,1 or 2 . Assessment of brace effectiveness included; 1) percentage of patients who have $5^{\circ}$ or less curve progression and the percentage of patients who have $6^{\circ}$ or more progression at skeletal maturity, 2) percentage of patients who have had surgery recommendation/undergone before skeletal maturity.

\section{Results}

At three years follow up a correction was achieved in $50 \%$ of treated patient and only in $9.5 \%$ of controls, stabilization in $23.1 \%$ treated and $33.4 \%$ in controls and progression in $26.9 \%$ for the treated group and 59.1\% for controls. Three immature patients required surgical fusion while receiving treatment (11.5\%) as well as 3 control patients (14.3\%). For the control patients we considered as a failure if the Cobb angle worsened by more then $5^{\circ}$ from the original angle and the patient then received treatment.

Sainte-Justine Hospital, Montreal, Canada

\section{Conclusions}

The SpineCor brace is effective for the treatment of early adolescent idiopathic scoliosis comparing with its natural history. Moreover, the positive outcome appears to be maintained in the long term.

Published: 27 January 2012

\section{References}

1. Coillard C, Circo A, Rivard CH: A new concept for the non-invasive treatment of adolescent idiopathic scoliosis: the corrective movement principle integrated in the SpineCor system. Disabil Rehabil Assist Technol 2008, 3(3):112-9.

2. Coillard C, Circo AB, Rivard $\mathrm{CH}$ : SpineCor treatment for juvenile idiopathic scoliosis: SOSORT award 2010 winner. Scoliosis 2010, 5:25.

doi:10.1186/1748-7161-7-S1-O24

Cite this article as: Coillard et al.: A prospective randomized study of the natural history of idiopathic scoliosis versus treatment with the SpineCor brace. Scoliosis 2012 7(Suppl 1):O24.
Submit your next manuscript to BioMed Central and take full advantage of:

- Convenient online submission

- Thorough peer review

- No space constraints or color figure charges

- Immediate publication on acceptance

- Inclusion in PubMed, CAS, Scopus and Google Scholar

- Research which is freely available for redistribution
C Biomed Central

(c) 2012 Coillard et al; licensee BioMed Central Ltd. This is an open access article distributed under the terms of the Creative Commons 